\title{
A Critical Assessment on Nepal's Journey to Socialism
}

\author{
Sangam Chaulagain \\ Lecturer, Makawanpur Multiple Campus \\ email: sangamhtd2040@gmail.com
}

Received: November 09, 2020; Revised \& Accepted: December 11, 2020; Published: February 18, 2021 (C) Copyright: Chaulagain (2021).

\begin{abstract}
This article makes a critical assessment on Nepal's journey to socialism. Nepal, through its constitution, has formally promised to lead the eco-politics of this country to the path of socialism. This article discusses the current initiatives that have been taken by the state after the constitution of 2015 formally announced socialism as the guiding eco-political principle of the nation. This article has been prepared on the basis of qualitative research through the secondary information collected from various sources. Although a formal promise has been made for socialism in the constitution, Nepal is highly influenced by capitalist system, and the rulers are under the clutch of neo-liberalism. The documents of major political parties show that they are trying to move forward in the path of social democracy, but they need to make radical corrections in their practical behaviors and performances to establish socialist eco-political culture in Nepal.
\end{abstract}

Key Words: capitalism, communism democracy, political parties, socialism

\section{INTRODUCTION}

Nepal promulgated a new constitution in 2015 (2072 BS) through Constituent Assembly with the approval of almost ninety percent members of the assembly. The constitution has unanimously incorporated the agenda of socialism in its preamble and has promised to lead the nation towards socialist direction. The preamble affirms that the nation will be committed to socialism based on democratic norms and values (The Constitution of Nepal, 2015). In the same way, article four of part one writes "Nepal is an independent, indivisible, sovereign, secular, inclusive, democratic, socialism-oriented, federal democratic republican state" $(2015$, p. 8). This provision shows the common commitment of all executors and followers of the constitution towards socialist journey of the nation.

The major political parties of Nepal have made promise to develop Nepal as socialist state. The journey of Nepali Congress, one of the largest and eldest democratic parties, started politics before seventy years with the slogan घर हुन्छ पोत्नेको, जमिन हुन्छ जोत्नेको, the real owner of the 
house is the one who resides and takes cares of it, the real owner of the land is the one who cultivates it] (1955). The first manifesto of Nepal Communist Party, the largest and ruling party in Nepal today, begins with the slogan: पहाड पर्वत खोला नाला जगगा जमीन सबको/मालिक हामी दास बनों किन हिस्सा सबमा सबको! [These lands, hills, rivers belong to all people / We are the owners not the slaves as we have equal possession] (1947). Those slogans project the assurance of these two major parties on establishing socialism in the nation. The third largest party of Janata Samajbadi Party (People's Socialist Party) and other smaller communist parties are also dedicated to socialist agenda. These parties have reflected their aspirations while drafting the constitution of Nepal in 2015.

As the agenda of socialism has been incorporated in the constitution, it is essential to begin the journey of the nation towards it. The real journey begins with the promotion of public ownership in the means of production, adoption of socialist market economy and development of socialist culture in society. Mishra (2019) claims that it is less probable to make socialistoriented eco-politics possible in Nepal at present as the condition of production is very low and the politics of ethnic and religious identity are parallelly moving ahead. In this sense, implementation of socialist agenda is politically and economically very challenging today which the parties themselves have agreed on. Despite this situation, they have promised to begin the journey towards it.

There are several models of socialism in the world. Originally, socialism was formulated and forwarded by Marxist theory as a way to reach up to communist system globally. Many corrections and reformations have taken place in socialist theory, and Nepal has also promised to promote socialist norms and values incorporating democratic norms and values within it. This kind of provision in Nepal seems to be much nearer to social democratic practices of northwestern European countries, especially Scandinavian countries where they have capitalist production system, but have strongly valued the provision of social and economic justice. Although the promise of socialism has been made in the constitution of Nepal, the eco-political direction does not seem to be in right direction yet.

\section{Defining Socialism}

Socialism is an eco-political philosophy which advocates for state ownership of all means of production providing equal rights and opportunities to all citizens. This philosophy believes that state has to take responsibility of the welfare and justice of every citizen in the nation. Mises (1981) opines that socialism is basically concerned with the idea of equality. Socialist system considers every worker as a producer and speaks for their role in decision of what to produce and how to produce. According to Mishra (2019), socialism considers private ownership of property as the root cause of social pollution and evil. To uproot private ownership is essential for establishing socialism.

The aim of Socialism is to transfer the means of production from private ownership to the ownership of organized society, the State (Mises, 1981). For Mises "It is impossible to discuss Socialism at all without having first and foremost examined the mechanism of an economic order 
based on public ownership of the means of production" (p. 27). Public ownership of means of production is the foundation for socialism.

The theory of socialism was first developed by the founder of Marxist philosophy Karl Marx. He coined this terminology to speak against 'capitalism'. Marxists define capitalism as a system in which "production is governed by capital calculations" (Mises, 1981, p. 96). In capitalist society an individual is free to own means of production privately and is free to make profit as much as he/she can. Mishra (2019) considers capitalism as cruel social system because in this system the one who can fight in competition can progress; the one who cannot, falls down and never rises up. It means capitalism always favors the powerful one.

Some capitalist nations have endeavored to make some corrections in their state policies accumulating the concerns of social and economic justice due to the influence of socialist theory, but "social inequality is an inevitable dimension of the capitalist world system" (Baer, 2016, p. 12). Socialism and capitalism are two contrasting ruling policies in which ownership of means of production and role of state are more significant aspects of differences. Socialism rejects private ownership of property while capitalism considers private ownership as fundamental freedom of individual. Similarly, socialism demands for strong and all determining government in the state while capitalism considers government just as a referee in open market economy. In socialism "the state is seen as the most effective vehicle for coordinating and administering to the needs of all" (Esenwein, 2004, p. 2227). Esenwein also argues that socialism is directly opposite to the highly individualistic order advocated by the proponents of laissez faire economics.

Mises (1981) argues "Capitalist society is the realization of what we should call economic democracy” (p. 20). In capitalist society every individual has right to private ownership with the right to make as much profit as possible through legal means. Socialists criticize that capitalist mode of production promotes few powerful investors and exploits rest of the workers in society. Capitalism considers humans as commodity that can be bought in the market in cheap price. Mises further mentions that socialists accuse capitalism that there is "relentless exploitation of wage-slaves by the pitiless rich" (p. 96). Socialism regards every human being as politically conscious being, and it focuses on the right of every citizen to work and make a comfortable living. It stresses on communalism and collectivism instead of highlighting on individualism and competition. The aim of socialism is to make possible for everyone an adequate existence (Mises, 1922). Socialism believes upon equality for all and the guarantee of basic requirements of all citizens.

Socialist theory believes that only a few and powerful investors can progress in capitalism because only those few people own the means of production and resources. Large number of physical and mental labors, who lack capital for investment, lose the battle of economic as well as political competition. In capitalism, justice, equality and opportunity to working class people are impossible. The capitalists exploit and utilize maximum recourses of the nation for their benefit due to which majority of the citizens are deprived of equitable distribution of resources. Baer (2016) opines that a serious redistribution of the world's resources 
is essential for an adequate standard of living for everyone on the earth. Baer further argues that reinvention of the notion of socialism is required to distribute resources equitably to everyone with enough, but not too much. The imbalance in the distribution of the world's recourses is that some own more, but some none; some labor much, but some none.

Capitalism serves few capitalists in the society and causes income and wealth inequality, so socialists have advocated for state solutions of that inequality (The Council of Economic Advisers, 2018). Socialists believe that capitalism does not last longer as it has been highly flourishing inequality among people and unhealthy competition among investors in the matter of owning resources. They believe that socialism is a natural outcome of social development. Marxism believes that socialism will replace capitalism naturally as feudalism was automatically replaced by capitalism.

The theory of socialism has undergone a massive reformation in the course of time. When Marx and Engels introduced the theory of socialism as a reaction to extreme labor exploitation and market economy in European land, they were determined that the extreme partition between haves and have nots in society would not be resolved unless the provision of private ownership were outlawed. They also believed that working class people would never be able to compete with upper class capitalists. So, socialists advocate for the society of communalism instead of competition. The mission for Marxists, classically, was to create a communist world in which socialism was considered to be the "way to a classless and stateless society, communism" (Esenwein, 2004, p. 2228). The dream of communism today has almost been missing as socialist movement in the world is in defensive position. Socialism and capitalism today have affected each other and many capitalist countries have taken up some socialist agenda to escape from the spoil of capitalism.

Democratic socialism has become the compromising agenda today for many communist parties in the world. Many other non-communist countries have also incorporated socialist agenda in their state policies and programs. It is hard to find countries with pure capitalist or socialist nature in the globe today. Democratic socialism is the combination of socialist and capitalist theories in which social justice and welfare state policies of socialist movement are incorporated with individual freedom, market competition of capitalist agenda. Mishra (2019) states that democratic socialism doesn't attack ownership; it doesn't attack production profit, either; it allows for production ownership, private profit and expansion of private production, but collects heavy tax from profit; rather, it attacks on distribution (236). In this system of socialism, the capitalists who make large profit out of their investment pay certain tax to the government, and the tax is used to uplift the status of marginalized and powerless citizens in the nation.

\section{Nepali Political Parties and Socialism}

Most of the existing political parties of Nepal have agreed upon the aim of developing this nation as a socialist nation. They have signed for the promulgation of today's constitution which has articulated commitment for socialism in its preamble. The party that is formed and that functions under the guidance of present constitution cannot go against the outline of 
socialism. So, directing the nation toward socialist path is the common assurance of Nepali political parties.

Formation of political parties and rule of party government started in Nepal in the periphery of People's Revolution 1950. During the formation of Nepali political parties, the influence of British parliamentary system through India, and influence of communist system of Russia could be seen parallelly. As communism had been occupying authority in many Asian and European countries, Nepali politicians were also heavily influenced by the Communist Manifesto of Marxists. The two leading political parties then Nepal Communist Party and Nepali Congress were established almost in the same period before the revolution of 1950, which are leading the politics of Nepal even today.

As socialist agenda was burgeoning throughout the globe after the World War II, the journey of Nepali political parties also started with the agenda of socialism. B. P. Koirala, one of the founders of Nepali Congress, formulated the theory of Prajatantrik Samajbad (Democratic Socialism) in 1955 as the guiding principle of his party. Koirala was much influenced by Marxist concept of social justice and economic equality. In one of his interviews he agreed that he was Marxist in many contexts as he was influenced by the historical analysis of Marx (Acharya, 2010). He disagreed upon the autocratic ruling in communist countries in the name of Marxism and proletarians. He argued that autocracy was not Marxism, rather Marxism advocated for democratic rule of the nation (Acharya, 2010).

Blending the philosophy of Marxism and parliamentary democracy, Koirala put forward the seventeen points as the foundation for Democratic Socialism in Nepal. Out of those seventeen points individual freedom, fundamental rights, adult franchise, rule of law, decentralization as well as land reformation, legal rights of farmers, job security of labors and end of their exploitation, provision of incentive for backwarded communities are significant aspects. (Acharya, 2011). Koirala talks of both political and economic equality of citizens, and accuses communist countries for ignoring political freedom of individual (Acharya, 2011). He believed that socialism in real sense could not exist in the absence of democratic values.

The first manifesto of Nepal Communist Party, which appeared in 1947, strongly advocated for the establishment of socialism in Nepal. The communist founders of Nepal, led by Puspalal Shrestha were much influenced by the socialist rule of Russia and wanted to follow similar kind of system in Nepal. The manifesto also requested all the citizens to take the path in which destruction of existing feudal system and abolition of the domination of global imperialist capitalism, establishing people's rule under the leadership of hardworking labors; in another sense, establishing such ruling system in which citizens could become the owners of national property, and that property would be promoted for the benefit of those citizens. $(1947$, p. 12). The state under the leadership of working class people, elimination of every symptoms of feudalism, resistance to imperialist mission of western capitalists, promotion of national property and public ownership of national property were the chief ingredients of Communist Manifesto at that time. 
Under the leadership of Congress leader B. P. Koirala, a democratic government was formed with two-third majority in 1959. The government took some progressive steps in the nation by nationalizing forest, introducing land reformation program and abolishing Birta System (the provision in which powerful person holds large amount of land with the permission of rulers). The Koirala government was dissolved after one and a half years by the then king Mahendra, and Nepal underwent a party less Panchayat ruling system for about thirty years.

Democracy was re-established in Nepal in 1990 and Nepali Congress became the ruling party for many times. The government of Nepali Congress implemented western policy of liberalism and privatization instead of fulfilling the promise of socialism. Theoretically, it is still moving ahead with the slogan of Rastriyata, Prajatantra, Samajbad (Nationality, Democracy, Socialism). It means Congress still considers socialism as the highest peak of human civilization in its documents.

Nepal Communist Party (NCP) is the ruling party in Nepal today with nearly two-third majority in parliament. This party was formed with the union of two larger communist parties of Nepal [Communist Party of Nepal (United Marxist, Leninist) and Communist Party of Nepal (Maoist Center)] in 2018. The political report of this party (2018) has also clearly stated the aim of establishing socialism in Nepal. It promises that establishment of socialism is the long-term and strategic goal of Nepali political movement (p. 19). The report further states that establishing socialism through peaceful movement and democratic exercise is possible in the current condition of Nepal as it has been guaranteed by the constitution. Through this document NCP has expressed its commitment to democratic practice refusing the classical socialist practices exercised by some communist countries. The report assures that democratic exercise will not be curtailed in today's socialism; rather it will further be ascertained (p. 20). Elaborating the economic model and characteristics of socialism in today's context, the report states that rule of working class people, end of exploitation of working class people, promotion of production capacity, economic justice and assurance of livable life to working class people, justice in distribution, promotion of cooperative feelings, ecological protection are some major features of socialism in Nepal.

NCP gives preferences to the end of unproductive, dependent and consumer-based capitalism in Nepal that has been generated by the promotion of neo-liberalism, it stresses for strengthening the circulation of productive national capital and promotion of industrialization to generate high employment. (Political Report,2018). There are numerous questions upon the ruling communist party regarding the honesty towards socialism although the party is theoretically found strongly determined towards the journey of socialism.

\section{Journey of Socialism in Nepal}

It is surprising for the capitalist world that socialist movement in Nepal is not degrading as per the global expectation; rather it is becoming further influential. The communist party is elected with nearly the two-third majority in parliament. Most of the political parties, including the senior most democratic party Nepali Congress, have theoretically agreed upon socialism. 
This rare circumstance has become possible may be because the political parties of Nepal in their political doctrines are able to maintain balance between the people's concerns of democratic values and social justice. Even the communist parties have taken into consideration that capitalism cannot be ignored in today's global scenario though they believe that capitalism alone cannot do justice to the majority of the population who are powerless and poor. Mishra (2019) views that social democracy is the optimum limitation of class conflict in the current global context as it is impossible to avoid capitalism for the countries like Nepal. Achievement of classical socialist system is far from today's reality.

Pena (2014) deals with the six essential components for sustainable socialism that are crucial to combat bourgeois liberalization. The six components as he defines are: an economic system that builds productive forces and promotes common prosperity, a political system that fulfils people's demand for democracy, strong and sovereign socialist state, progressive socialist culture, resource management meeting people's economic needs, and resistance to bourgeois liberalization (pp. 267/68). Pena also stresses on the need of "socialist-oriented market economy" (p. 271) for the sustainability of socialism.

While evaluating the journey of Nepali political parties to socialist trail, it is worthwhile to assess their theoretical and practical standpoints through the lens of Pena's six components. After the reestablishment of democracy in 1990, Nepali Congress ruled over the nation with majority in parliament. It was a golden opportunity for the party to implement the agenda of democratic socialism as promised by their founders. Instead, Congress leaders got heavily influenced by neo-liberal economic policies of the west. Tobias Gombert (2009) claims "newliberal position assumes that the freedom of the market is enough to ensure the freedom of the individual" (p. 65). The government of Nepali Congress exercised the policy of open market economy, liberalization and privatization as the key features of its economic policy in the name of individual freedom. Pokhrel (2018) claims that Nepali congress begged the alms of capitalist economic system in the golden plate of democratic socialism due to which the working class citizens are unhappy with this party. The indulgence of capitalist market economy led Congress leaders away from the theory of socialism.

Nepali Congress is unclear in the vision of socialism though it has incorporated socialism as a fundamental aspect of its political mission. They insist that their concept of socialism is different from communist perception of socialism, but they are not able to make clear roadmap to meet the mission of socialism. Congress senior leader Shekhar Koirala pinpoints the necessity of redefining and redescribing the theory of nationality, democracy and socialism as per the need of today (2018). Another Congress leader Bishwa Prakash Sharma (2018) clarifies that the terminology of the constitution socialism-oriented has to be contextually defined and described by Nepali Congress to lead the nation for long-term future. These remarks of Congress leader give us a clear concept that this party has not made any theoretically clear preparation to fulfill the demand of socialism in Nepal. 
Nepal Communist Party accepts in political report (2018) that there is the domination of broker capitalism in Nepali economic system. It further claims that some broker capitalists earn money through mediation between producers and consumers instead of any investment of capital. Those capitalists are being supported by powerful politicians and beaurocrates. The report also clarifies that this kind of capitalism obstructs the promotion of national capital. Although this party is the ruling political party at present, it confesses that the nation is in the very inaugural phase of socialism, and time has not come to accomplish the socialist movement at present (Political Report, 2018). NCP believes that capitalism has to be matured and national capital has to be stronger to accomplish the movement of socialism.

Mishra (2019) opines that for strong national capital, promotion of the cycle of reinvestment and reproduction needs to be rigorous and effective within the nation which is basically absent in our context. Due to this reason, both the investors and workers are deprived of benefit. In current context of Nepal, upper and middle class people have been able to hold political and economic power in society (Mishra, 2019). They have been investing in the field of health, education, land, housing and other easy income sectors, and becoming influential in every social and political institution. They have promoted the culture of consumerism, rather than the culture of production.

As stated by Pena (2014), progressive socialist culture and state sovereignty are very significant issues in the socialist movement of Nepal. The leaders of communist parties, who have theoretically committed to make the journey of socialism and reach up to communism, are found the owners of huge private enterprises. They know very well that socialism cannot be achieved unless private ownership is stepped down, but they have invested huge amounts in private institutions like hospitals, schools and colleges, industries, land and housing, and many other service sectors. The leaders who had to promote socialist culture in society are found heavily influenced by capitalist culture. Pena (2014) further opines "the population of the socialist homeland must be brought up in a vigorous, progressive, rich and wide ranging socialist culture" (p. 270). The clear orientation of socialist culture is lacking in our country which is obstructing the journey of socialism. The communist leaders are also found influenced by prosperous investors in decision making. Though they have promised to establish socialism in Nepal, it has not become easy for themselves to come out of the clutch of capitalist culture.

State sovereignty can also be a challenge for us to establish socialism in Nepal. Pena (2014) views that to make a sovereign socialist homeland, an independent nation that is capable of standing up for itself and its people are essential. Nepal has never lost its political sovereignty in history. But in today's scenario, its independence in decision making has been challenged by many other anti-socialist nations. The political report of Nepal Communist Party (2018BS) has also accepted that foundation of socialism can be prepared if only the nation is able to develop national industrial capital displacing the domination of monopoly capitalism and establish economic independence. Economic independence is basic requirement for sovereignty which is 
International Research Journal of MMC (IRJMMC)

Vol. 2

Issue 1 (February, 2021)

ISSN 2717-4999 (Online)

2717-4980 (Print)

lacking in Nepal. In this context, it is challenging for Nepal to build a sustainable socialist society.

Mishra (2019) thinks that time has come for the state rulers to evaluate upon the progress in the implementation of their promise made in the constitution. Many years have passed even after promulgating the constitution committed to socialism. It is time to think of how many community schools, hospitals and other community institutions have been opened up (Mishra, 2019). If privatization keeps expanding, and our leaders cannot break their affiliations with corrupted billionaires, Nepal cannot make the journey of socialism even if it is printed in the constitution.

\section{Way Forward}

The unique feature of Nepali politics is that it always fought for democratic values, but it has preferred socialist philosophy as dominant ruling ideology. Especially after the reestablishment of democracy in 1990, larger portion of popular votes have been casted upon communist parties in every election. Nepali communist parties have also directly or indirectly acknowledged multiparty democracy, and have incorporated democratic values practically. The capitalist notion of plurality and individual freedom, and socialist notion of social and economic justice have amalgamated in the politics of Nepali society. Mises (1981) asserts that political democracy is the product of liberalism, but people require economic as well as political equality in democracy. Economic democracy is best available in socialist practice, so unification of both political and economic equality is the requirement today.

The political report of Nepal Communist Party (2018) also realizes the need of some kind of reformation in classical Marxism. The report states that Nepali model of socialism will be further strengthened with the provisions of multiparty system, adult franchise, periodic election, elected government, provision of opposition, rule of law etc. incorporating them as the fundamental factors. It does not speak against the promotion of national capital, as it believes that national capital must be promoted for state independence. Mishra (2019) believes that capitalism must be matured first to begin the journey of socialism, but capitalism in Nepal is immature and in wrong track. Mishra advocates for social democracy as the most appropriate political program in today's context of Nepal. Capitalism has to be strengthened for the promotion of employment and national income. At the same time, justice to labor, equitable distribution of resources, promotion of backwarded and marginalized people are the agenda which should go ahead parallelly. Mishra further stresses that social democracy is in a sense the combination of both capitalism and socialism in which capital and labor are negotiated.

Even though capitalism has supported for technological advancement, Baer (2016) discusses two major weaknesses of capitalism that are: uneven distribution of wealth and resources, and depletion of natural resources. He further states:

While capitalism has produced numerous impressive technological innovations, some

beneficial and others destructive, which are very unevenly distributed, it is a system fraught with numerous contradictions, including: growing social disparities within most 
nation states, authoritarian and militarist practices, depletion of natural resources, environmental degradation, including global warming and associated climatic changes, species extinction, and population growth as a by-product of poverty (p. 2).

Baer's argument tries to clarify that for the sustainability of eco-friendly global economic development, excessive exploitation of natural resources and their uneven distribution have to be controlled. He strongly advocates for democratic socialism that "would involve not only democracy in the workplace but also citizen involvement in the operation of educational institutions, health facilities, housing associations, and other organizations that impact people's lives" (p. 4).

The advocates of socialism today clearly know that capitalism cannot be ignored in the current global scenario. It is only possible to make necessary corrections in classical capitalist notions to adjust in local context, and incorporate socialist agenda within it to make it progressive and equitable. In The Idea of Communism, Tariq Ali (2009) argues that twenty-first century socialism should include political pluralism, freedom of speech, access to the media, the right to form trade unions, and cultural liberty. Authoritarian and centralized ruling system in the name of communism is not possible in today's context. So, democratic values must be incorporated within socialism. State ownership of all means of production is not possible in modern socialism. Instead, promotion of public ownership in the field of health and education, provision of social security, freedom for private investment and right to reproduction of private ownership, preservation of the rights of labors, tax on profit can be some of the economic provisions in current context.

Tobias Gombert (2009) talks about the core values of social democracy in which freedom, equality and justice, and solidarity are major values. These core values have more concern on the formation of humanitarian society. Respecting the core values of social democracy as stated by Gombert, a nation should not control individual capacity and creativity. An individual has to be free to make every kind of career growth through legal means. Privatization and liberalization create heavy disparity between the rich and the poor. So, instead of just playing the role of a referee, the state needs to be stronger for providing justice to marginalized people. Excessive privatization in the field of education and health does not create equitable society. In these kinds of public sectors, public ownership has to be promoted. The problem in Nepal for socialist journey is that health and education sectors are in the hand of limited capitalists who have been able to influence powerful state rulers.

Baer (2016) claims that socialism must be promoted for the sustainability of ecology and for equitable distribution of natural resources. He uses the term Democratic Eco-Socialism that "rejects a statist, growth-oriented, productivist ethic and recognizes that humans live on an ecologically fragile planet with limited resources that must be sustained and renewed as much as possible for future generations" (P. 6). Baer views that to shift the world to democratic ecosocialism, a revolution is required in various ways depending on the national context. He also 
argues that there is a possibility of capitalists to resist such revolution. So, formation of socialist state is not an easy task today.

The ultimate requirement of communist parties in Nepal is to incorporate the policies and programs of democratic socialism. It helps them to get rid of the charge that communist believe upon totalitarianism. The essential requirement for them to walk in the path of socialism is to control unrestrained privatization in the fields like health and education, and to avoid their nexus to powerful and broker capitalists who are the agents to pollute the mission of strengthening national capital. Nepali political parties must be clear in the definition of socialism, and must be able to resist western neo-liberal economic policy. Otherwise, their promise to socialism becomes a fake promise to deceive the Nepali citizens.

\section{CONCLUSION}

From the time of People's Revolution 1950, Nepali sentiment was much impressed by socialist philosophy. Politically, the people always stood for democracy, but economically they always supported socialist values. So, Nepali political parties have directly or indirectly incorporated socialism in their manifestos and political documents. They have also promised to orient Nepali political and economic journey towards socialism.

Although the parties have theoretically promised to begin the journey to socialism, their practical activities, the culture and schooling they have promoted, their nexus to capitalists, extreme privatization in education and health sectors, uncontrolled expenditure during the election, luxury of party leaders, hold of financial donors in the powerful posts of parties, and augmentation in the distance between rich and poor signify that the journey of socialism is still far from the reality in Nepal.

\section{REFERENCES}

Acharya, J.R. (2010, September 9). [Interview with B. P. Koirala]. The Kantipur Daily.

Acharya, N. (2011). Nepalko Sandarvama Samajbad (Socialism in Nepali Context). B. P.

Smarika. B. P. Chintan Pratisthan, Makawnpur, 1-4.

Ali, T. (2009). The Idea of Communism. London: Seagull Books.

Baer, H. A. (2016). Toward Democratic Eco-socialism as the Next World System. USA: The next System project.

Esenweln, G. (2004). Socialism. New Dictionary of the History of Ideas. 2227-2235. Retrived from https://www.researchgate.net/publication/311885000

Gombert, T. (2009). Foundations of Social Democracy. Berlin, Germany: Friedrich-EbertStiftung.

Gyanwali, P. (2011). Nepali Rajnitima B. P. Koirala (B.P. Koirala in Nepali Politics). B. P. Smarika. B. P. Chintan Pratisthan, Makawnpur, 25-28.

Koirala, S. (2018). Nepali Congress Bachaune Abako Bato (Today's Path to Save Nepali Congress). B. P. Smarika. B. P. Bichar Samaj, Makawanpur, 135-137. 
Mises, L. V. (1981). Socialism: An Economic and Sociological Analysis. Trans. J. Kahane. Liberty Fund. http://oll.libertyfund.org/title/1060.

Mishra, C. (2019). Loktantra Ra Aajako Marxbad (Democracy and Today's Marxism). Ed. Rajendra Maharjan. Kathmandu: Book Hill Publication.

Nekapako Pahilo Ghosanapatra (First Manifesto of NCP). (1947). Puspalalka Chhanieka Rachanaharu, Part One. rajaneeti.com.

Nepal Communist Party (NCP). (2019) Rajnitik Pratibedan. Kathmandu: Central Office.

Pena, D. S. (2014). The Six Essential Components of Sustainable Socialism: From Building the Productive Forces to Combating Bourgeois Liberalization. International Critical Thought, 4(3), 267-288. http://dx.doi.org/10.1080/21598282.2014.930987

Pokhrel, B. Pd. (2018). B. P. Ko Samajbad Vuleko Nepali Congress ko Netritwa (Leadership of Nepali Congress forgetting B.P.'s Socialism). B. P. Smarika. B. P. Bichar Samaj, Makawanpur, 113-115.

Sharma, B. Prk. (2018). Congress Rupantaranko Agenda (Agenda for Transforming Congress). B. P. Smarika. B. P. Bichar Samaj, Makawanpur, 119-122.

The Constitution of Nepal. (2015). The Secretariat of Constituent Assembly. Singhadarbar, Kathmandu. English Translated Version.

The Council of Economic Advisors. (2018). The Opportunity Cost of Socialism. The Executive Office of the President, Whitehouse: USA. 